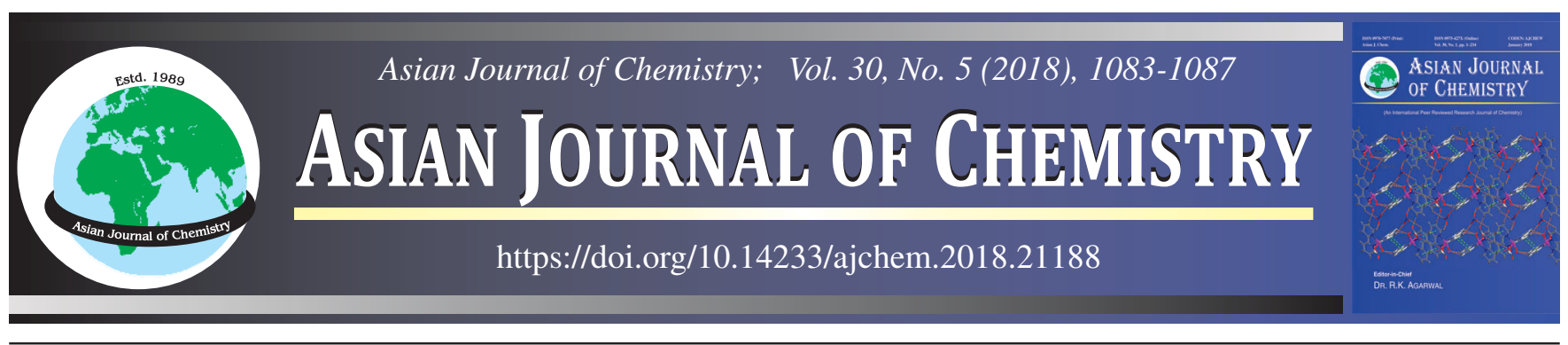

\title{
Removal of Hexavalent Chromium from Water and Organic Solvent Mixed Media by Adsorption Using Weak Base Anion Exchanger Tulsion A-2X (MP)
}

Prasanna S. Koujalagi, Sanjaykumar V. Divekar* and Raviraj M. Kulkarni

Department of Chemistry, KLS Gogte Institute of Technology (Autonomous), Belagavi-590 008, India

*Corresponding author: Fax: +91 831 2441909; Tel: +91 831 2498511; E-mail: pskoujalagi@ git.edu

The removal of a most common toxic, environmental pollutant and carcinogen chromium(VI) was studied by batch technique for the adsorption and ion exchange method from water and organic solvent mixed media under various conditions like interaction time, $\mathrm{pH}$, effect of organic solvents and temperature. Maximum adsorption of chromium(VI) on Tulsion A-2X (MP) was in the optimum pH range of 5.0-5.5. Increase in temperature decreased the adsorption of chromium(VI). Interaction time indicated that about $70 \%$ removal of chromium(VI) was within $15 \mathrm{~min}$. Chromium(IV) adsorption was discussed based on first order kinetics and adsorption isotherms.

Keywords: Hexavalent chromium, Adsorption and ion exchange, Kinetics, Themodynamics, Anion exchanger Tulsion A-2X. L

\section{INTRODUCTION}

Chromium is commonly used in electroplating, tanning, photography, steel, ceramic, fungicides, glass, paint and pigment manufacturing units. Wastewaters generated from these industries having chromium(VI) which is very toxic [1]. Usually its concentration in water medium varies from $10-100 \mathrm{mg} \mathrm{L}^{-1}$. Studies have indicated that in biological systems $\mathrm{Cr}(\mathrm{VI})$ can behave as carcinogenic, mutagenic and teratogenic [2]. Removal of $\mathrm{Cr}$ (VI) has become today a major concern due to its hazardous effects on health and environment such as high risk of lung cancer, damages to liver, kidney, nervous system and modification of DNA transcription $[3,4]$. Permissible limit for total chromium in water is $0.05 \mathrm{mg} \mathrm{L}^{-1}$ [5]. Proper treatment of chromium(VI) is very much essential prior discharge of chromium containing water into natural water sources. Various physico-chemical methods have been suggested in the literature for the removal of chromium(VI) such as precipitation, electrolysis, ion exchange, reverse osmosis, adsorption, solvent extraction, etc. [6]. However, these methods have either expensive, require technical knowledge or they have considerable disadvantages including the generation and disposal of solid residues which causes a secondary pollution [7]. Simple and eco-friendly method among the available is ion exchange and adsorption. The technique ion exchange and adsorption gives an effective treatment of chromium(VI) from water and organic solvent mixed media.

Presently, the purpose of this work is to remove hexavalent chromium from water and organic solvent mixed media using weak base resin Tulsion A-2X (MP). For removing chromium(VI) from aqueous media under acidic conditions, generally weak base ion exchange resins are used [8]. Mixed water-organic solvents media is specially considered as the solvents are widely used in paint and pigment industries and hence there is a possibility of presence of solvents in water medium for the adsorption of chromium(VI) [9]. The resin efficiency in adsorption of chromium(VI) is described under various conditions like, effect of temperature, effect of $\mathrm{pH}$, effect of interaction time and effect of organic solvents. Adsorption isotherms, thermodynamic and kinetic parameters have also been evaluated.

\section{EXPERIMENTAL}

Analytical reagent grade chemicals and reagents were used in the experiments and procured from Himedia Company, India. 2-Methoxyethanol and 2-ethoxyethanol solvents were procured from Acros Organics, USA. Weak base ion exchange resin Tulsion A-2X (MP) used in the present study was supplied by Thermax Ltd., Pune, India. The physico-chemical properties of Tulsion A-2X (MP) are listed in Table-1. Reconditioned and air dried resin was used in the experimental work. Known molar concentrations of $\mathrm{K}_{2} \mathrm{CrO}_{4}$ solutions were prepared in water and organic solvent mixed media.

Equilibrium studies: Adsorption experiments were made by stirring $30 \mathrm{~mL}$ of potassium dichromate solutions and $0.025 \mathrm{~g}$ of resin Tulsion A-2X (MP) in water and organic solvent mixed media for $6 \mathrm{~h}$ using batch technique at constant temperatures of 303,313 and $323 \mathrm{~K}$ in a thermostatically controlled 


\begin{tabular}{ll}
\hline \multicolumn{1}{c}{$\begin{array}{c}\text { TABLE-1 } \\
\text { PHYSICO-CHEMICAL CHARACTERISTICS OF } \\
\text { WEAK BASE ION EXCHANGE RESIN }\end{array}$} \\
\hline Resin & $\begin{array}{l}\text { Tulsion A-2X (MP), } \mathrm{Cl}^{-} \text {form } \\
\text { Resin type }\end{array}$ \\
& $\begin{array}{l}\text { Anionic weak base exchanger with } \\
\text { macroporous structure }\end{array}$ \\
Matrix & Polystyrene copolymeric \\
Functional group & Tertiary amine \\
Resin bead size (mm) & $0.3-1.2$ \\
Percentage of moisture & 47 \\
Exchange capacity per $250 \mathrm{~g}$ & 0.90 meq. \\
Stability & $80{ }^{\circ} \mathrm{C}$ \\
pH range & $0-9$ \\
Screen size & $16-40$ US mesh \\
\hline
\end{tabular}

laboratory shaker and after equilibration chromium(VI) concentration in solution was measured by UV-visible spectrophotometer (Varian Cary 50 Bio) at $540 \mathrm{~nm}$ using 1,5-diphenylcarbazide method [10,11]. Distribution coefficient $\left(\mathrm{K}_{\mathrm{d}}\right)$ values were determined using the following equation [9]:

$$
\mathrm{K}_{\mathrm{d}}=\frac{\mathrm{q}_{\mathrm{e}}}{\mathrm{C}_{\mathrm{e}}}
$$

where $\mathrm{q}_{\mathrm{e}}\left(\mathrm{mol} \mathrm{g}^{-1}\right)$ is the quantity of metal ions adsorbed at equilibrium and $\mathrm{C}_{\mathrm{e}}\left(\mathrm{mol} \mathrm{L}^{-1}\right)$ is the concentration of metal ions in the solution at equilibrium.

Percentage of removal of chromium(VI) from water and organic solvent mixed media was calculated using eqn 2 :

$$
\mathrm{R}(\%)=\frac{\left(\mathrm{C}_{\mathrm{o}}-\mathrm{C}_{\mathrm{e}}\right)}{\mathrm{C}_{\mathrm{o}}} \times 100
$$

where $\mathrm{C}_{\mathrm{o}}$ and $\mathrm{C}_{\mathrm{e}}$ are the initial and equilibrium concentrations of chromium(VI) in $\mathrm{mol} \mathrm{L}^{-1}$.

\section{RESULTS AND DISCUSSION}

Effect of interaction time: The effect of interaction time on adsorption of chromium(VI) on Tulsion A-2X (MP) at neutral $\mathrm{pH}$ and temperature $303 \mathrm{~K}$ is represented in Fig. 1. It revealed that adsorption of chromium(VI) increases with increase in period of contact. About $70 \%$ adsorption of chromium(VI) was achieved within $15 \mathrm{~min}$ [8]. A maximum of $97.2 \%$ adsorption of chromium(VI) was at $225 \mathrm{~min}$. The percentage adsorption of chromium(VI) was rapid upto $120 \mathrm{~min}$ because of the existence of greater percentage of resin sites for the exchange. Later there was a gradual increase in the adsorption rate upto $225 \mathrm{~min}$. Further increase in interaction time decreases the adsorption of chromium(VI) due to lack of available sites on the resin phase.

Effect of pH: The influence of $\mathrm{pH}$ on the adsorption of chromium(VI) by Tulsion A-2X (MP) was studied in $\mathrm{pH}$ range of 4 to 8 . Fig. 2 showed that adsorption of chromium(VI) was maximum (95.91\%) at $\mathrm{pH} 5$ for an initial chromium concentration of $0.0011 \mathrm{M}$. On increasing the $\mathrm{pH}$ more than 5 , a continuous decrease in the adsorption of chromium(VI) was observed by Tulsion A-2X (MP). This decrease at higher $\mathrm{pH}$ may be attributed to the competition between hydroxyl ions and chromate ions to occupy the active sites of Tulsion A-2X (MP) [12]. Hence, it is concluded that the percentage of adsorption of $\mathrm{Cr}(\mathrm{VI})$ is maximum on weak base resin in the $\mathrm{pH}$ values between 5.0 - 5.5.

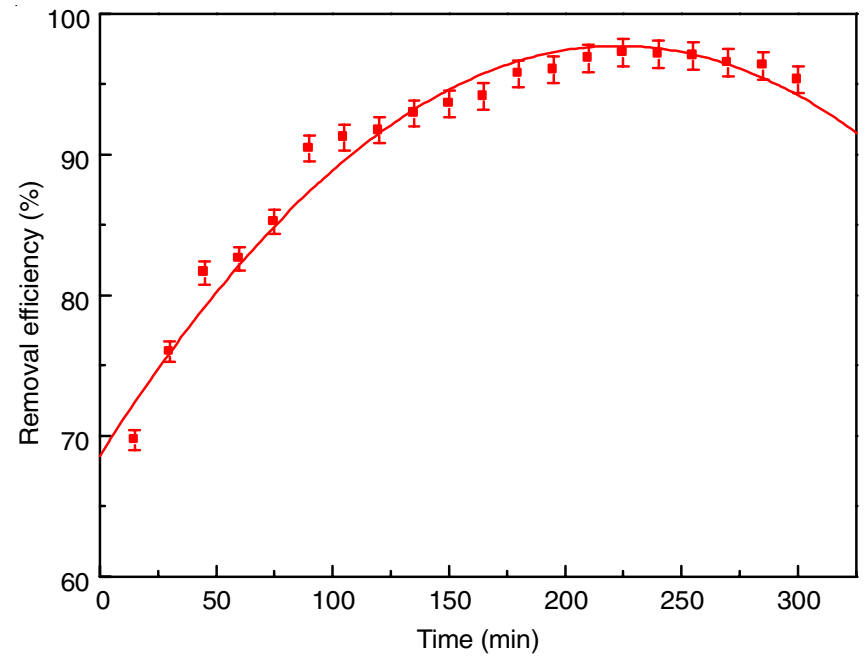

Fig. 1. Effect of interaction time on the adsorption of chromium(VI) by Tulsion A-2X (MP)

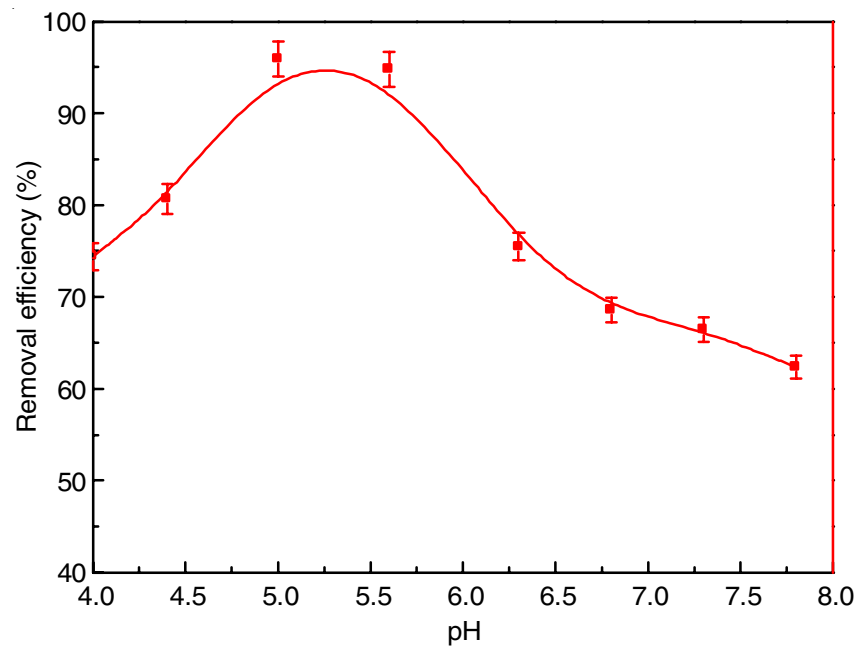

Fig. 2. Variation of $\mathrm{pH}$ for of adsorption of chromium(VI) by Tulsion A2X (MP)

Effect of temperature: Adsorption of chromium(VI) on Tulsion A-2X (MP) was studied as a function of temperature in the range $303 \mathrm{~K}$ to $323 \mathrm{~K}$ (Table-2). The decrease in adsorption rate with rise in temperature may be due to the desorption process caused by an increase in the available thermal energy. The desorption process is influenced by higher temperature and is due to higher mobility of adsorbate [13,14].

Thermodynamic parameters viz., change in Gibbs free energy $(\Delta \mathrm{G})$, change in enthalpy $(\Delta \mathrm{H})$ and change in entropy $(\Delta \mathrm{S})$ are required to predict the nature of adsorption of chromium(VI) on Tulsion A-2X (MP). The free energy change for the adsorption of chromium(VI) has been calculated by eqn 3 .

$$
\Delta \mathrm{G}=-\mathrm{RT} \ln \mathrm{K}_{\mathrm{d}}
$$

where $\mathrm{R}$ is the universal gas constant, $\mathrm{T}$ is the temperature and $K_{d}$ is the equilibrium distribution coefficient.

The $\Delta \mathrm{H}$ values are calculated using van't Hoff equation (eqn. 4) and the change in entropy values are calculated using eqn. 5 .

$$
\ln \frac{\mathrm{K}_{2}}{\mathrm{~K}_{1}}=\frac{-\Delta \mathrm{H}}{\mathrm{R}}\left(\frac{1}{\mathrm{~T}_{2}}-\frac{1}{\mathrm{~T}_{1}}\right)
$$




\begin{tabular}{|c|c|c|c|}
\hline \multicolumn{4}{|c|}{$\begin{array}{c}\text { TABLE-2 } \\
\text { EQUILIBRIUM DISTRIBUTION COEFFICIENTS FOR } \\
\text { ADSORPTION OF CHROMIUM(VI) ON TULSION A-2X (MP) } \\
\text { IN WATER AND ORGANIC SOLVENT MIXED MEDIA } \\
\text { AT 303, } 313 \text { AND } 323 \mathrm{~K}\end{array}$} \\
\hline Solvent & $\begin{array}{c}\text { Temperature } \\
(\mathrm{K})\end{array}$ & $\begin{array}{c}\text { Organic } \\
\text { solvent }(\%)\end{array}$ & $\log K_{d}$ \\
\hline \multirow{15}{*}{ 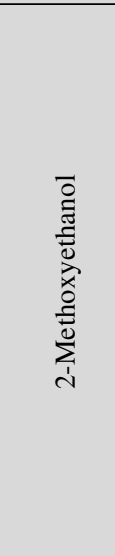 } & \multirow{5}{*}{303} & 00 & 1.8077 \\
\hline & & 20 & 1.6674 \\
\hline & & 40 & 1.4513 \\
\hline & & 60 & 1.0194 \\
\hline & & 80 & 0.9224 \\
\hline & \multirow{5}{*}{313} & 00 & 1.7975 \\
\hline & & 20 & 1.6011 \\
\hline & & 40 & 1.2752 \\
\hline & & 60 & 0.9510 \\
\hline & & 80 & 0.7889 \\
\hline & \multirow{5}{*}{323} & 00 & 1.6874 \\
\hline & & 20 & 1.5621 \\
\hline & & 40 & 1.2351 \\
\hline & & 60 & 0.9184 \\
\hline & & 80 & 0.7481 \\
\hline \multirow{15}{*}{ 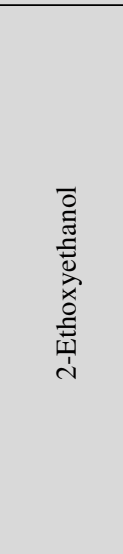 } & \multirow{5}{*}{303} & 00 & 1.8077 \\
\hline & & 20 & 1.5531 \\
\hline & & 40 & 1.2129 \\
\hline & & 60 & 0.8694 \\
\hline & & 80 & 0.7937 \\
\hline & \multirow{5}{*}{313} & 00 & 1.7975 \\
\hline & & 20 & 1.5006 \\
\hline & & 40 & 1.1972 \\
\hline & & 60 & 0.8126 \\
\hline & & 80 & 0.7694 \\
\hline & \multirow{5}{*}{323} & 00 & 1.6874 \\
\hline & & 20 & 1.4721 \\
\hline & & 40 & 1.1495 \\
\hline & & 60 & 0.8121 \\
\hline & & 80 & 0.6742 \\
\hline
\end{tabular}

$$
\Delta \mathrm{G}=\Delta \mathrm{H}-\mathrm{T} \Delta \mathrm{S}
$$

where $K_{1}$ and $K_{2}$ are the values of equilibrium distribution coefficients at constant temperatures of $T_{1}$ and $T_{2}$ respectively.

The values of enthalpy change $(\Delta \mathrm{H})$ in negative sign revealed that energy was released as the adsorption of chromium(VI) on Tulsion A- 2X (MP) proceeds [15]. As there is increase in temperature and organic solvent contents from 20 to $80 \%(\mathrm{w} / \mathrm{w})$ the values of $\Delta \mathrm{G}$ also increase (Table-3). This indicates that adsorption was less favored at high temperatures and higher solvent compositions. Spontaneity of the process was confirmed by the negative values of $\Delta \mathrm{G}$. The variation in $\Delta \mathrm{S}$ showed that organic solvent compositions can produce a kind of disorder in the water structure. Change in negative entropy may be due to the decreased randomness on the resin-solution interface and the positive entropy change may be due to the release of water during the adsorption of chromium(VI) $[16,17]$.

Effect of organic solvents: The study was made to investigate the effect of solvents and dielectric constant of the media on the adsorption of chromium(VI). From Table-2, the adsorption of chromium(VI) decreases with increase in percentage of organic solvents from 20 to $80 \%$ at all temperatures studied. This may be attributed to the decrease in the ionization of inorganic salt in solution. Upon addition of organic media, 2-methoxyethanol and 2-ethoxyethanol, the extent of equilibrium distribution coefficient decreases due to decrease in dielectric constant of the medium and thus causing decrease in adsorption process of chromium(VI).

Kinetics studies: Weak base anionic exchanger Tulsion A-2X (MP) was used in present work to understand the effect of change in resin fixed ion on kinetics of exchange of chromium(VI). The sorption of chromium(VI) from solution phase to resin phase may be given as:

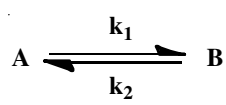

where $\mathrm{k}_{1}$ and $\mathrm{k}_{2}$ are the rate constants for forward and backward reactions. Using the equation mentioned in Gode and Pehlivan [18] and the plot of $\ln \left(1-U_{t}\right)$ against time $t$ (Fig. 3), the overall kinetic rate constant $\mathrm{k}$, forward and backward kinetic rate constants $k_{1}$ and $k_{2}$ were determined [18,19]. It was observed from Table- 4 that $\mathrm{k}_{1}$ was much better than $\mathrm{k}_{2}$. This depicts the predominance of adsorption of chromium(VI) on Tulsion A2X (MP).

Adsorption isotherms: The dispensation of solute across two regions of liquid and solid sorbent is the assessment of adsorption process and can popularly be described using Freundlich and Langmuir models.

Freundlich isotherm is represented by eqn. 6 as follows:

\begin{tabular}{|c|c|c|c|c|c|c|c|}
\hline \multicolumn{8}{|c|}{$\begin{array}{l}\text { TABLE-3 } \\
\text { THERMODYNAMICAL PARAMETERS FOR THE ADSORPTION OF CHROMIUM(VI) IN } \\
\text { WATER AND ORGANIC SOLVENT MIXED MEDIA ON TULSION A-2X (MP) }\end{array}$} \\
\hline & \multicolumn{3}{|c|}{$\Delta \mathrm{G}\left(\mathrm{kJ} \mathrm{mol}^{-1}\right)$} & \multicolumn{2}{|c|}{$\Delta \mathrm{H}\left(\mathrm{kJ} \mathrm{mol}^{-1}\right)$} & \multicolumn{2}{|c|}{$\Delta \mathrm{S}\left(\mathrm{J} \mathrm{K}^{-1} \mathrm{~mol}^{-1}\right)$} \\
\hline & $303 \mathrm{~K}$ & $313 \mathrm{~K}$ & $323 \mathrm{~K}$ & $303-313 \mathrm{~K}$ & $313-323 \mathrm{~K}$ & $303-313 \mathrm{~K}$ & $313-323 \mathrm{~K}$ \\
\hline \multicolumn{8}{|c|}{ 2-Methoxyethanol $(\%, \mathrm{v} / \mathrm{v})$} \\
\hline 00 & -10.5 & -10.8 & -10.4 & -1.85 & -21.3 & 28.5 & -33.7 \\
\hline 20 & -9.7 & -9.6 & -9.5 & -12.0 & -11.4 & -7.8 & -5.8 \\
\hline 40 & -8.4 & -7.6 & -7.6 & -32.0 & -7.8 & -77.8 & -0.4 \\
\hline 60 & -5.9 & -5.7 & -5.7 & -12.4 & -6.3 & -21.5 & -1.9 \\
\hline 80 & -5.4 & -4.7 & -4.6 & -24.2 & -7.9 & -62.4 & -10.1 \\
\hline \multicolumn{8}{|c|}{ 2-Ethoxyethanol $(\%, \mathrm{v} / \mathrm{v})$} \\
\hline 00 & -10.5 & -10.8 & -10.4 & -1.85 & -21.3 & 28.5 & -33.7 \\
\hline 20 & -9.0 & -8.9 & -9.1 & -9.6 & -5.5 & -2.0 & 11.1 \\
\hline 40 & -7.0 & -7.2 & -7.1 & -2.9 & -9.2 & 13.8 & -6.6 \\
\hline 60 & -5.0 & -4.9 & -5.0 & -10.3 & -0.1 & -17.4 & 15.3 \\
\hline 80 & -4.6 & -4.6 & -4.2 & -4.4 & -18.4 & 0.63 & -44.1 \\
\hline
\end{tabular}




\begin{tabular}{|c|c|c|c|c|}
\hline \multicolumn{5}{|c|}{$\begin{array}{r}\text { TABLE-4 } \\
\text { KINETIC PARAMETERS FOR THE ADSORPTION OF }\end{array}$} \\
\hline Adosrbent & $\begin{array}{l}\text { Amount of chromium(VI) } \\
(\mathrm{mmol})\end{array}$ & $\begin{array}{c}\text { Overall kinetic rate } \\
\text { constant, } \mathrm{k}=\mathrm{k}_{1}+\mathrm{k}_{2}\left(\mathrm{~min}^{-1}\right)\end{array}$ & $\begin{array}{l}\text { Forward kinetic rate } \\
\text { constant, } \mathrm{k}_{1}\left(\mathrm{~min}^{-1}\right)\end{array}$ & $\begin{array}{l}\text { Backward kinetic rate } \\
\text { constant, } \mathrm{k}_{2}\left(\mathrm{~min}^{-1}\right)\end{array}$ \\
\hline Tulsion A-2X (MP) & 1 & 0.0225 & 0.0216 & 0.0009 \\
\hline
\end{tabular}

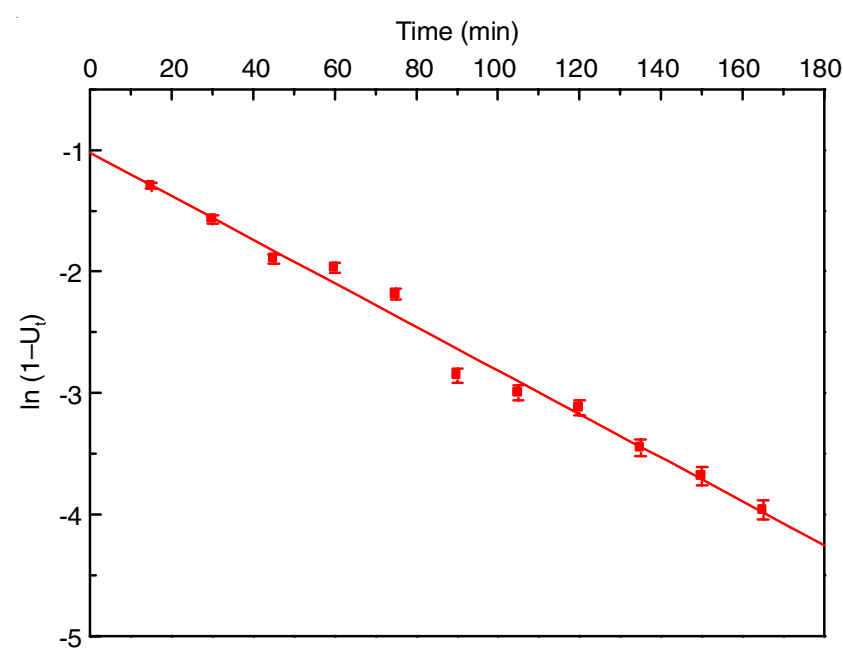

Fig. 3. Kinetic plot for the adsorption of chromium(VI) on Tulsion A-2X (MP)

$$
\left(\frac{\mathrm{x}}{\mathrm{m}}\right)=\mathrm{kC}_{\mathrm{e}}^{1 / \mathrm{n}}
$$

where $\mathrm{x} / \mathrm{m}\left(\mathrm{mg} \mathrm{g}^{-1}\right)$ is the quantity of chromium(VI) adsorbed per unit weight of the adsorbent, $\mathrm{C}_{\mathrm{e}}\left(\mathrm{mg} \mathrm{L}^{-1}\right)$ is the concentration at equilibrium, $\mathrm{k}$ and $\mathrm{n}$ are Freundlich constants indicating adsorption capacity and intensity, respectively.

Freundlich model (Fig. 4) shows the favourable adsorption of chromium(VI) and the values of Freundlich constants are given in Table-5. Higher value of $\mathrm{n}$ shows the adsorption rate of chromium(VI) on resin phase [20].

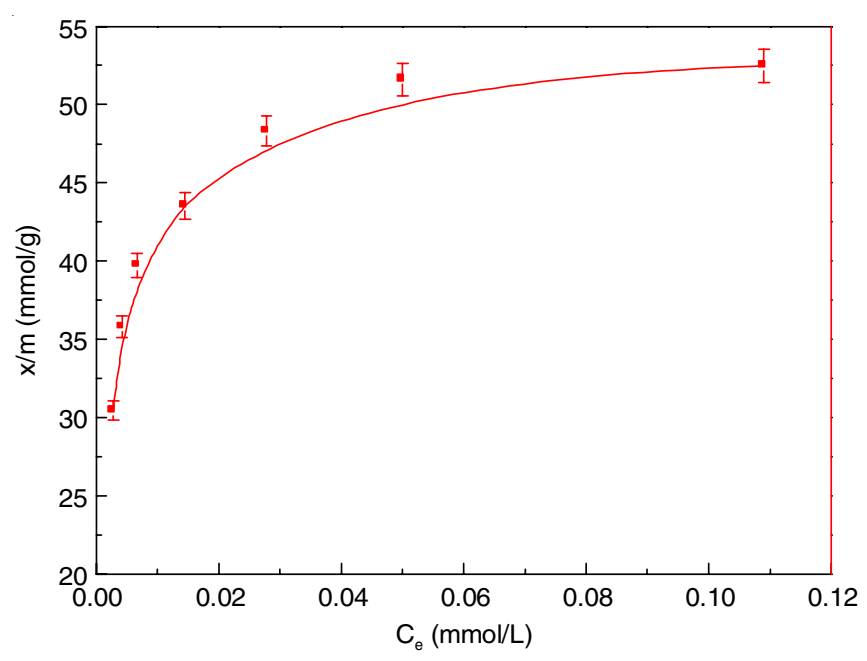

Fig. 4. Freundlich adsorption isotherm for chromium(VI) on Tulsion A$2 \mathrm{X}(\mathrm{MP})$
Langmuir isotherm is represented by eqn. 7 as follows:

$$
\frac{\mathrm{C}_{\mathrm{e}}}{\mathrm{q}_{\mathrm{e}}}=\frac{1}{\mathrm{~K}_{\mathrm{b}} \mathrm{A}_{\mathrm{s}}}+\frac{\mathrm{C}_{\mathrm{e}}}{\mathrm{A}_{\mathrm{s}}}
$$

where $\mathrm{q}_{\mathrm{e}}$ is amount of adsorption of chromium(VI) per unit weight of the resin, $\mathrm{A}_{\mathrm{s}}\left(\mathrm{mol} \mathrm{g}^{-1}\right)$ and $\mathrm{K}_{\mathrm{b}}\left(\mathrm{L} \mathrm{mol}^{-1}\right)$ are the constants representing capacity and energy, respectively. Fig. 5 shows the validity of adsorption of chromium(VI) on Tulsion A-2X (MP).

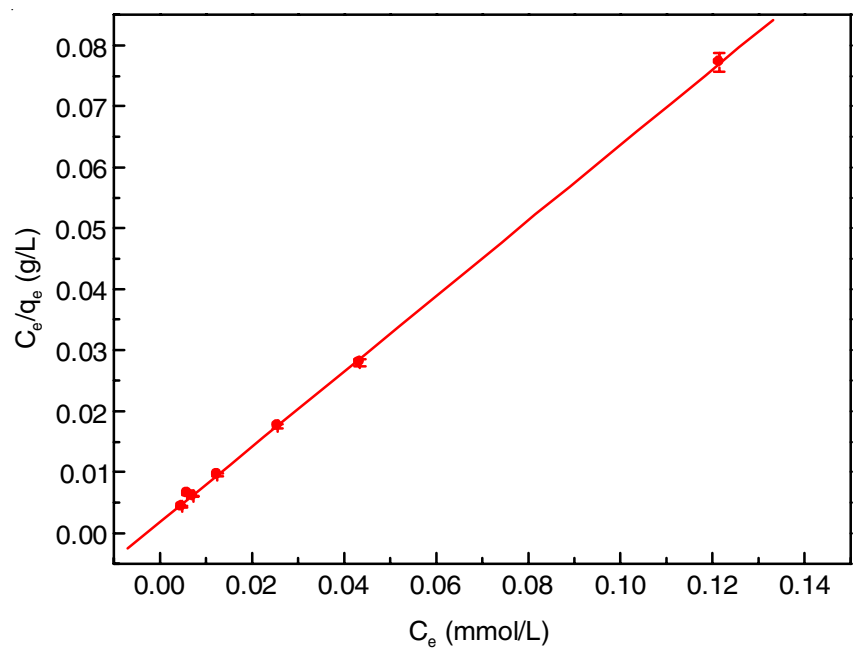

Fig. 5. Langmuir adsorption isotherm for chromium(VI) on Tulsion A-2X (MP)

Langmuir isotherm is expressed as separation factor $\mathrm{R}_{\mathrm{L}}$, an essential dimensionless parameter $[21,22]$ as per the eqn 8 .

$$
\mathrm{R}_{\mathrm{L}}=\frac{1}{1+\mathrm{K}_{\mathrm{b}} \mathrm{C}_{\mathrm{o}}}
$$

where $C_{o}$ is initial concentration of chromium(VI) in $\mathrm{mg} / \mathrm{L}$. The calculated value of $R_{L}$ is 0.728 indicated the favourable $\left(0<\mathrm{R}_{\mathrm{L}}<1\right)$ adsorption [23] of chromium(VI) on Tulsion A2X (MP).

\section{Conclusion}

The present study revealed that the Tulsion A-2X (MP) is an effective adsorbent for the adsorption of chromium(VI) from water and organic solvent mixed media. The optimum $\mathrm{pH}$ for the maximum adsorption of chromium(VI) on Tulsion A- 2X (MP) was between 5.0-5.5. Interaction time indicated that about $70 \%$ removal of chromium(VI) was within $15 \mathrm{~min}$ and maximum of $97 \%$ removal was acheived within $225 \mathrm{~min}$. The change in Gibbs free energy with negative values showed

TABLE-5

PARAMETERS OF FREUNDLICH AND LANGMUIR MODELS FOR ADSORPTION OF CHROMIUM(VI) ON TULSION A-2X (MP)

\begin{tabular}{ccc|cccc}
\hline \multicolumn{3}{c|}{ Freundlich adsorption isotherm } & \multicolumn{4}{c}{ Langmuir adsorption isotherm } \\
\hline $\mathrm{k}$ & $\mathrm{n}$ & $\mathrm{R}^{2}$ & $\mathrm{~K}_{\mathrm{b}}$ & $\mathrm{A}_{\mathrm{S}}(\mathrm{mmol} / \mathrm{g}$ resin) & $\mathrm{R}^{2}$ & $\mathrm{R}_{\mathrm{L}}$ \\
\hline 77.62 & 6.95 & 0.92 & 340.16 & 1.62 & 0.99 & 0.728 \\
\hline
\end{tabular}


that ion-exchange and adsorption processes on Tulsion A- 2X (MP) were favourable with spontaneity. Kinetics and adsorption models gave the best feasibility data of chromium(VI) and it was well interpreted by separation factor $\mathrm{R}_{\mathrm{L}}$ between 0 to 1 . Thus, it is concluded that the ion-exchange resin Tulsion A-2X (MP) could be employed in the removal of chromium(VI) from water and organic solvent mixed media.

\section{ACKNOWLEDGEMENTS}

The authors are grateful to Visvesvaraya Technological University, Belagavi, India for the grants under the project (Ref: VTU/Aca-RGS/2008-2009/7180). The authors are thankful to Thermax Ltd., Pune, India for the supply of resin sample.

\section{REFERENCES}

1. Y. Gu and X. Zhu, Mikrochim. Acta, 173, 433 (2011); https://doi.org/10.1007/s00604-011-0578-3.

2. R.M. Sedman, J. Beaumont, T.A. McDonald, S. Reynolds, G. Krowech and R. Howd, J. Environ. Sci. Health, 24, 155 (2006); https://doi.org/10.1080/10590500600614337.

3. U.S. Environmental Protection Agency, Guidance for Data Useability in Risk Assessment, Part A (1992).

4. S. Edebali and E. Pehlivan, Chem. Eng. J., 161, 161 (2010); https://doi.org/10.1016/j.cej.2010.04.059.

5. P.S. Koujalagi, S.V. Divekar, R.M. Kulkarni and R.K. Nagarale, Desalination Water Treat., 51, 3273 (2013); https://doi.org/10.1080/19443994.2012.749049.

6. S. Gupta and B.V. Babu, Chem. Eng. J., 150, 352 (2009); https://doi.org/10.1016/j.cej.2009.01.013.

7. B. Galan, D. Castaneda and I. Ortiz, Water Res., 39, 4317 (2005); https://doi.org/10.1016/j.watres.2005.08.015.

8. G. Kabir and S.E. Ogbeide, Int. J. Environ. Res., 2, 377 (2008).

9. P.S. Koujalagi, S.V. Divekar, R.M. Kulkarni and E.M. Cuerda-Correa, Desalination Water Treat., 57, 23965 (2016); https://doi.org/10.1080/19443994.2016.1138329.
10. A.D. Eaton, L.S. Clesceri and A.E. Greenberg, American Public Health Association (APHA), AWWA, WPCE: Washington D.C., vol. 4 (1995).

11. APHA, AWWA, WEF, "Standard Methods for Examination of Water and Waste Water, Washington-DC, New York, edn 20 (1998).

12. S.S. Baral, S.N. Das and P. Rath, Biochem. Eng. J., 31, 216 (2006); https://doi.org/10.1016/j.bej.2006.08.003.

13. P.K. Pandey, S.K. Sharma and S.S. Sambi, Int. J. Environ. Sci. Technol., 7, 395 (2010); https://doi.org/10.1007/BF03326149.

14. E. Pehlivan and S. Cetin, J. Hazard. Mater, 163, 448 (2009); https://doi.org/10.1016/j.jhazmat.2008.06.115.

15. S.I. Sandler, Chemical and Engineering Thermodynamics, John Wiley \& Sons, New York, USA, edn 3 (1999).

16. I.-H. Lee, Y.-C. Kuan and J.-M. Chern, J. Chinese Inst. Chem. Eng., 38, 71 (2007); https://doi.org/10.1016/j.jcice.2006.11.001.

17. Y.H. Li, Z. Di, J. Ding, D. Wu, Z. Luan and Y. Zhu, Water Res., 39, 605 (2005); https://doi.org/10.1016/j.watres.2004.11.004.

18. F. Gode and E. Pehlivan, J. Hazard. Mater., 100, 231 (2003); https://doi.org/10.1016/S0304-3894(03)00110-9.

19. J. Pradhan, S.N. Das and R.S. Thakur, J. Colloid Interface Sci., 217, 137 (1999); https://doi.org/10.1006/jcis.1999.6288.

20. G. McKay, H.S. Blair and J.R. Gardner, J. Appl. Polym. Sci., 27, 3043 (1982); https://doi.org/10.1002/app.1982.070270827.

21. S.V. Mohan, N.C. Rao and J. Karthikeyan, J. Hazard. Mater, 90, 189 (2002); https://doi.org/10.1016/S0304-3894(01)00348-X.

22. T.W. Weber and R.K. Chakravorti, J. Am. Inst. Chem. Eng., 20, 228 (1974); https://doi.org/10.1002/aic.690200204.

23. A. Sari, M. Tuzen, D. Citak and M. Soylak, J. Hazard. Mater, 149, 283 (2007); https://doi.org/10.1016/j.jhazmat.2007.03.078. 